\title{
Antioxidant Activity of Spices and Their Impact on Human Health: A Review
}

\author{
Alexander Yashin ${ }^{1}$, Yakov Yashin ${ }^{1}$, Xiaoyan Xia ${ }^{2}$ and Boris Nemzer ${ }^{2,3, *}$ \\ 1 International Analytical Center of Zelinsky Institute of Organic Chemistry of Russian, Academy of Science, \\ 119991 Moscow, Russia; yashinchrom@mail.ru (A.Y.); yashin@interlab.ru (Y.Y.) \\ 2 Department of Research \& Development, VDF FutureCeuticals, Inc., Momence, IL 60954, USA; \\ Susan.Xia@futureceuticals.com \\ 3 Food Science and Human Nutrition, University of Illinois at Urbana-Champaign, Urbana, IL 61801, USA \\ * Correspondence: bnemzer@futureceuticals.com; Tel.: +7-815-507-1427
}

Received: 30 May 2017; Accepted: 8 September 2017; Published: 15 September 2017

\begin{abstract}
Antioxidants are substances that prevent oxidation of other compounds or neutralize free radicals. Spices and herbs are rich sources of antioxidants. They have been used in food and beverages to enhance flavor, aroma and color. Due to their excellent antioxidant activity, spices and herbs have also been used to treat some diseases. In this review article, the chemical composition and antioxidant activity of spices and culinary herbs are presented. The content of flavonoids and total polyphenols in different spices and herbs are summarized. The applications of spices and their impacts on human health are briefly described. The extraction and analytical methods for determination of antioxidant capacity are concisely reviewed.
\end{abstract}

Keywords: antioxidants; spices; herbs; flavonoids; polyphenols

\section{Introduction}

Herbs and spices have been used in many different ways. Since the ancient times, spices and culinary herbs have been added to food to enhance flavor and improve their organoleptic properties. Spices and herbs have also been widely used as preservatives and medicine.

Spices and herbs have been extensively studied in different countries because of the high antioxidant activity in certain spices and their beneficial effects on human health [1-22]. As part of our diet, spices and herbs, in addition to fruits and vegetables, could provide us with additional sources of natural antioxidants. Antioxidants from spices are a large group of bioactive compounds which consist of flavonoids, phenolic compounds, sulfur-containing compounds, tannins, alkaloids, phenolic diterpenes, and vitamins [7-9,11-13,16,21]. These compounds demonstrate different antioxidant activities. For example, flavonoids have the ability to scavenge free radicals and can form complexes with catalytic metal ions rendering them inactive. Studies have shown that spices and herbs such as rosemary, sage, and oregano are excellent sources of antioxidants with their high content of phenolic compounds.

Antioxidants can protect lipids and oils in food against oxidative degradation. When added to food, antioxidants control rancidity development, retard the formation of toxic oxidation products, maintain nutritional quality, and extend the shelf-life of products. Because of safety concerns, synthetic antioxidants are limited to be used as food preservatives. Natural antioxidants obtained from edible materials such as spices and herbs, have been of increasing interest.

Natural antioxidants contained in spices help to reduce oxidative stress. Oxidative stress, which is caused by high concentration of free radicals in cells and tissues, can be induced by various negative factors, such as gamma, UV, and X-ray radiation, psycho-emotional stress, polluted food, adverse environmental conditions, intensive physical exertion, smoking, alcoholism, 
and drug addiction. Chronic oxidative stress has been reported to lead to a variety of diseases, including cancer, heart related diseases, and the acceleration of aging. Several secondary products of lipid oxidation, such as malondialdehyde and 4-hydroxynonenal, can react with biological components such as proteins, amino acids, and DNA. Malondialdehyde has been shown to be formed both enzymatically and non-enzymatically, and has been implicated in health problems such as mutagenesis and carcinogenesis. Spices and culinary herbs are rich in antioxidants. Therefore, spices could potentially be used as ameliorative or preventive agents for some health issues $[5,6,10,13,14,16]$.

To have a better understanding of the antioxidant activity from spices, we present the bioactive compounds, the content of flavonoids, and the total polyphenols in different spices. The therapeutic effects of various spices for different diseases are summarized. Other applications of spices and herbs are briefly described in this review.

\section{Chemical Composition of Spices and Their Antioxidant Activity}

The antioxidant activity of spices is related to their chemical composition; primarily to the presence of polyphenolic and other biologically active compounds. Table 1 lists primary antioxidants and the biologically active compounds found in spices and culinary herbs that include flavonoids, phenolic acids, lignans, essential oils, and alkaloids, as summarized from several publications [23-25]. These compounds were largely determined by chromatographic methods.

Table 1. Chemical composition of spices (seasonings) and culinary herbs [23-25].

\begin{tabular}{|c|c|}
\hline Spices and Herbs & Important Chemical Constituents \\
\hline Cloves & $\begin{array}{c}\text { Eugenol, isoeugenol, acetyleugenol, sesquiterpene, pinene, vanillin, gallic acid, } \\
\text { flavonoids, phenolic acids }\end{array}$ \\
\hline Cinnamon & $\begin{array}{l}\text { Eugenol, limonene, terpineol, catechins, proanthocyanidins, tannins, linalool, safrole, } \\
\text { pinene, methyleugenol, benzaldehyde }\end{array}$ \\
\hline Cardamon & $\begin{array}{c}\text { Limonene, 1,8-cineole, terpinolene, myrcene, caffeic acid, quercetin, kaempferol, } \\
\text { luteolin, pelargonidin }\end{array}$ \\
\hline Coriander & $\begin{array}{l}\text { Linalool, borneol, geraniol, terpineol, cumene, pinene, terpinene, quercetin, } \\
\text { kaempferol, caffeic, ferulic, n-coumaric and vanillic acids, rutin, tocopherols, pyrogallol }\end{array}$ \\
\hline Saffron & $\begin{array}{l}\text { Crocins (water soluble carotenoids), safranal, flavonoids, gallic, caffeic, ferulic, } \\
n \text {-catechuic, syringic, salicylic, and vanillic acids }\end{array}$ \\
\hline Turmeric & $\begin{array}{l}\text { Curcumins, essential oils, eugenol, carotene, ascorbic acid, caffeic, } p \text {-coumaric, } \\
\text { protocatechuic, syringic, vanillic acid }\end{array}$ \\
\hline Ginger & $\begin{array}{c}\text { Gingerol, turmeric, paradol, geraniol, geranial, borneol, linalool, camphene, zingerol, } \\
\text { zingiberon }\end{array}$ \\
\hline Anise & $\begin{array}{l}\text { Camphene, pinene, linalool, trans-, cis-anetholes, eugenol, acetanisole, rutin, } \\
\text { luteolin-7-glucoside, apigenin-7-glucoside, isoorientin }\end{array}$ \\
\hline Caraway & $\begin{array}{c}\text { Monoterpenes, sesquiterpene, aromatic aldehydes, terpene esters, terpenol, terpenal, } \\
\text { terpenon, limonene, safranal, kaempferol, quercetin, tannins, caffeic, ferulic, } \\
\text { p-coumaric, and chlorogenic acids }\end{array}$ \\
\hline Fenugreek & Sesquiterpenes, aromatic aldehydes, terpenes \\
\hline Black pepper & Piperine, pinene, camphene, limonene, terpenes, piperidine, isoquercetin, sarmentine \\
\hline Oregano & $\begin{array}{l}\text { Apigenin, quercetin, luteolin, myricetin, diosmetin, eriodictyol, carvacrol, thymol, } \\
\text { rosmarinic, caffeic, } p \text {-coumaric, protocatechuic acid }\end{array}$ \\
\hline Basil & $\begin{array}{c}\text { Apigenin, catechins, quercetin, rutin, kaempferol, anthocyanins, eugenol, limonene, } \\
\text { terpinene, carvacrol, geraniol, menthol, safrole, tannins, ursolic, } p \text {-coumaric, rosmarinic } \\
\text { acids }\end{array}$ \\
\hline Bay leaf & 1,8-cineole, cinnamtannin \\
\hline Dill & Quercetin, kaempferol, myricetin, catechins, isorhamnetin, carvone, limonene \\
\hline Garlic & $\begin{array}{l}\text { Allicin, diallyl sulfide, diallyl disulfide, diallyl trisulfide, allyl isothiocyanate, } S \text {-allyl } \\
\text { cysteine }\end{array}$ \\
\hline Horseradish & Phenyl methyl isothiocyanate, allyl isothiocyanate, sinigrin, asparagine \\
\hline Allspice & Eugenol, gallic acid, pimentol, quercetin \\
\hline
\end{tabular}


Table 1. Cont.

\begin{tabular}{|c|c|}
\hline Spices and Herbs & Important Chemical Constituents \\
\hline Marjoram & $\begin{array}{l}\text { Limonene, pinene, terpinene, } p \text {-cumene, apigenin, ferulic, sinapinic, caffeic, syringic, } \\
\text { rosmarinic, } 4 \text {-hydroxybenzoic, vanillic acids }\end{array}$ \\
\hline Mustard & $\begin{array}{l}\text { Allyl isothiocyanate, carotene, isorhamnetin, isorhamnetin-7-O-glucoside, kaempferol } \\
\text { glucoside }\end{array}$ \\
\hline Fennelflower & $\begin{array}{l}\text { Pinene, } p \text {-cumene, thymoquinone, thymohydroquinone, thymol, carvacrol, nigellicine, } \\
\text { nigellidine, hederin }\end{array}$ \\
\hline Onion & Quercetin, apigenin, dipyridyl disulfide, rutin, quercetin-4-glucoside \\
\hline Parsley & Apigenin, luteolin, kaempferol, myricetin, quercetin, caffeic acid \\
\hline Red pepper & Capsaicin, tocopherol, lutein, carotene, capsanthin, quercetin, ascorbic acid \\
\hline Peppermint & $\begin{array}{l}\text { Menthol, menthone, limonene, isomenthone, eriocitrin, hesperidin, apigenin, luteolin, } \\
\text { rutin, carotenes, tocopherols, caffeic, rosmarinic, chlorogenic acid }\end{array}$ \\
\hline Rosemary & $\begin{array}{l}\text { Carnosol, rosmanol, geraniol, pinene, limonene, apigenin, naringin, luteolin, } \\
\text { rosmarinic, vanillic, ursolic, caffeic acids }\end{array}$ \\
\hline Sage & $\begin{array}{l}\text { Geraniol, pinene, limonene, carnosol, saponin, catechins, apigenin, luteolin, rosmarinic, } \\
\text { carnosine, vanillic, caffeic acids }\end{array}$ \\
\hline Nutmeg & Catechins, lignans, myricetin, orgentin, caffeic acid \\
\hline Myrtle & $\begin{array}{l}\text { Anthocyanins, pinene, limonene, gallic and ellagic acids, myrtocommulone, } \\
\text { myricetin-3-O-galactoside, myricetin-3-O-rhamnoside }\end{array}$ \\
\hline Lavender & $\begin{array}{l}\text { Limonene, quercetin, apigenin, kaempferol glucoside, ferulic, rosmarinic, caffeic, } \\
\qquad \text {-coumaric acid }\end{array}$ \\
\hline
\end{tabular}

The USDA (U.S. Department of Agriculture) Database contains information of flavonoid contents in spices and culinary herbs as determined by HPLC-UV (High performance liquid chromatography-UV detector) and HPLC-MS (High performance liquid chromatography-mass spectrometry) detection. The highest amounts of flavonoids have been found in parsley, oregano, celery, saffron, dill, fennel, and Tasmanian pepper (Table 2). Consumption of these spices and culinary herbs may contribute a significant portion of the plant antioxidants found in the human diet.

Table 2. Flavonoid content in spices from the USDA (U.S. Department of Agriculture) database on flavonoids content of selected foods, release 3.1 (2014) [26].

\begin{tabular}{|c|c|c|}
\hline Name & Flavonoid Content (mg per $100 \mathrm{~g}$ ) & $\begin{array}{l}\text { Total Flavonoid } \\
\text { Content }(\mathrm{mg} \text { per } 100 \mathrm{~g})\end{array}$ \\
\hline Parsley & Apigenin 4503.5, isorhamnetin 331.2, luteolin 19.7 & 4854.5 \\
\hline Mexican oregano & Luteolin 1028.7 , naringenin 372.0, eriodictyol 85.3, quercetin 42.0, apigenin 17.7 & 1550.79 \\
\hline Celery seeds & Luteolin 762.4 , apigenin 78.65 & 841.05 \\
\hline Capers & Kaempferol 259.19, quercetin 233.84 & 493.03 \\
\hline Saffron & Kaempferol 205.48 & 205.48 \\
\hline Dill & Quercetin 55.15, isorhamnetin 43.50 , kaempferol 13.33 , myricetin 0.70 & 112.68 \\
\hline Thyme & Luteolin 45.25 , apigenin 2.50 & 47.75 \\
\hline Fennel & Quercetin 48.80 , myricetin 19.80 , isorhamnetin 9.30 , kaempferol 6.50 , luteolin 0.10 & 84.50 \\
\hline Coriander, leaves & Quercetin 52.90 & 52.90 \\
\hline Wormwood & Quercetin 10.0, kaempferol 11.0, isorhamnetin 5.0, luteolin 1.0 & 27.0 \\
\hline Rosemary & Naringenin 24.86, luteolin 2.0, apigenin 0.55 & 27.41 \\
\hline Ginger & Kaempferol 33.60 & 33.60 \\
\hline Mustard & Kaempferol 38.20, quercetin 8.80, isorhamnetin 16.20 & 62.90 \\
\hline Sage & Luteolin 16.70 , apigenin 1.20 & 17.90 \\
\hline Red onion & $\begin{array}{c}\text { Quercetin 20.30, isorhamnetin } 4.58 \text {, delphinidin } 4.28 \text {, cyanidin } 3.19 \text {, peonidin } 2.07 \text {, } \\
\text { kaempferol } 0.65 \text {, apigenin } 0.24\end{array}$ & 35.31 \\
\hline Chile pepper & Quercetin 14.70 & 14.70 \\
\hline Yellow pepper & Quercetin 50.63, luteolin 6.93 & 57.56 \\
\hline Tasmanian pepper & Cyanidin 752.68 & 752.68 \\
\hline Garlic & Quercetin 1.74 , myricetin 1.61 , kaempferol 0.26 & 3.61 \\
\hline
\end{tabular}

Ten flavonoids with significant quantity have been identified in different spices. The most frequently found compounds were quercetin, luteolin, and kaempferol. The highest flavonoid contents were as follows: apigenin in dried parsley, luteolin in Mexican oregano, luteolin in celery seeds, 
and cyanidin in Tasmanian pepper. The greatest amount of kaempferol and quercetin was found in capers.

Table 3 shows the most biologically active compounds contained in various spices and their chemical structures. Many of them have been reported to be anti-carcinogenic and their actions have been studied separately. These compounds also have other important therapeutic effects and antioxidant activities. Various research and review articles related to the antioxidant activity of spices have been published during the last decade [12,13,16-21,27-51].

Table 3. The major biologically active compounds found in spices and herbs.

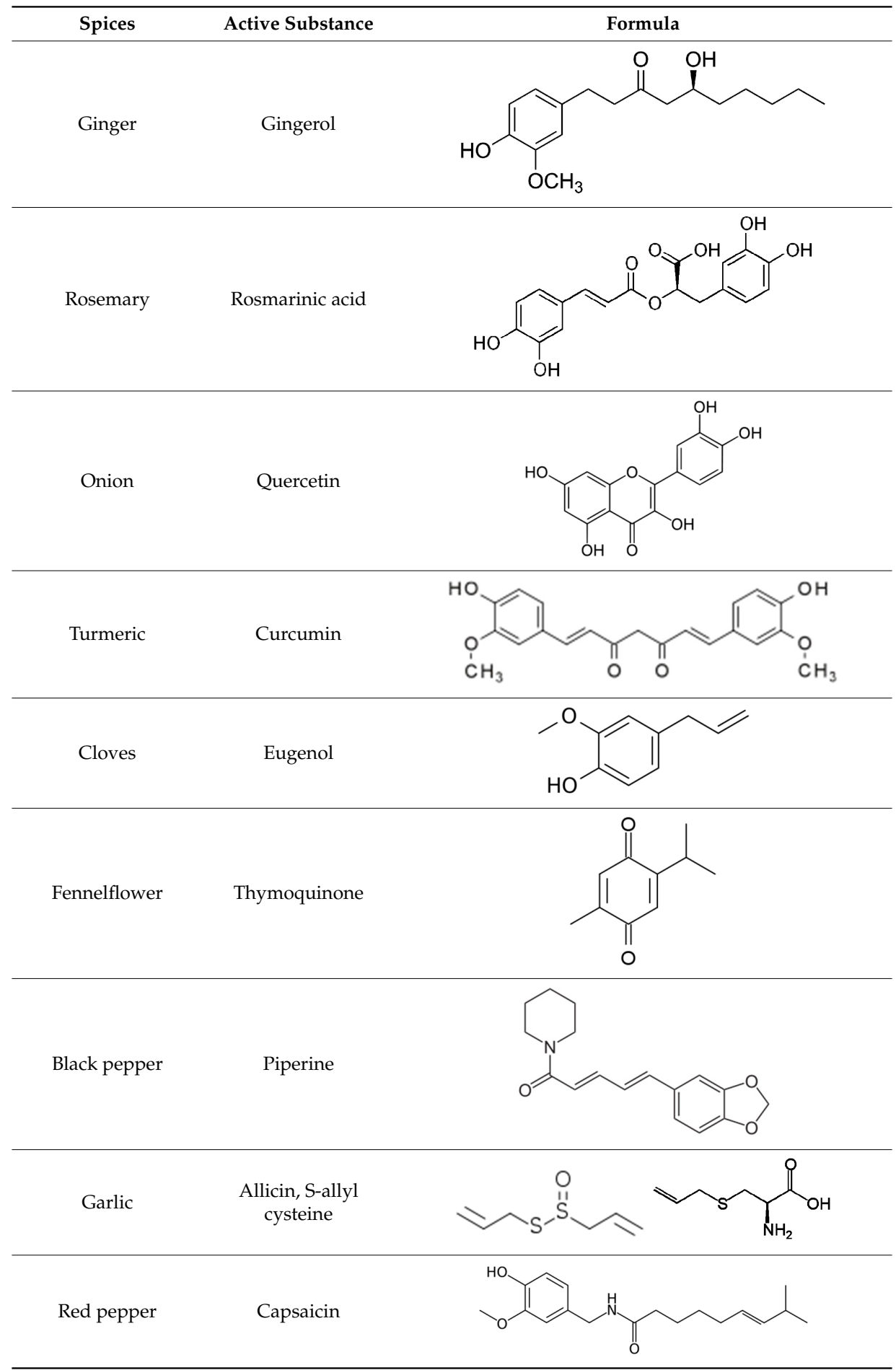


Table 3. Cont.

Spices

\subsection{Rosmarinic Acid in Spices}

Among these biologically active compounds found in spices, rosmarinic acid was the dominant phenolic compound in the six spices of the family Labiatae which contributed significantly to the antioxidant capacity of these spices. Shan et al. [27] investigated the total equivalent antioxidant capacity and phenolic content of 26 common spice extracts from 12 botanical families. In their study, major phenolic compounds were identified and quantified in different spices. Rosmarinic acid was found in mint, sweet basil, oregano, rosemary, sage, and thyme. The spices with the highest content of rosmarinic acid were oregano (2562.7, mg per $100 \mathrm{~g}$ of dry weight), sage (2186.1), rosemary (1286.1), mint (1908.5), sweat basil (1086.1), and thyme (681.1) respectively. Vallverdú-Queralt et al. [52] studied the phenolic profile of widely used culinary herbs and spices, which included rosemary, thyme, oregano, cinnamon, cumin and bay. The main phenolic acid in the studied culinary herbs was found to be rosmarinic acid, which varied from $0.39 \mu \mathrm{g} / \mathrm{g}$ dry weight in bay, to $157 \mu \mathrm{g} / \mathrm{g}$ dry weight in rosemary, being the dominant phenolic compound in oregano, thyme and rosemary. The concentrations of rosmarinic acid in rosemary, oregano, cumin, cinnamon, thyme and bay are: $156.90 \pm 3.20,52.02 \pm 1.74,3.29 \pm 0.12,0.73 \pm 0.09,84.04 \pm 2.75$ and $0.39 \pm 0.01 \mu \mathrm{g} / \mathrm{g}$. 
Nagy et al. [53] analyzed the phenolic components in dried spices and found that rosmarinic acid was one of the main constituents in the methanolic extracts of oregano, sage and thyme, which was consistent with other research.

Zheng and Wang [54] investigated antioxidant activity and phenolic compounds in selected herbs. Rosmarinic acid and hydroxycinnamic acid compounds have been demonstrated to possess strong antioxidant activity. Rosmarinic acid was the most abundant phenolic constituents in the sage extracts $117.8 \mathrm{mg} / 100 \mathrm{~g}$ of fresh weight. Oregano extracts also had high contents of rosmarinic acid (124.8-154.6 mg/100 g of fresh weight). Thyme and rosemary were known to have high antioxidant capacities with high contents of rosmarinic acid $(91.8 \mathrm{mg} / 100 \mathrm{~g}$ of fresh weight). It was found that certain species of oregano had extremely high total phenolic contents and oxygen radical absorption capacity (ORAC) values as well.

\subsection{Flavonoids in Spices}

Typically flavonoids and phenolic acids are the main phenolics in spices that possess antioxidant activity. Flavonoids generally occur as glycosylated derivatives with apigenin and luteolin are commonly found in aromatic herbs such as parsley, rosemary, thyme; quercetin and kaempferol in onions.

The antioxidant activity of phenolic compounds is mainly due to their redox propertiessuch as adsorbing and neutralizing free radicals, quenching singlet and triplet oxygen, or decomposing peroxides. In general, flavonoids have higher antioxidant activities against peroxyl radicals than do phenolic acids due to multiple hydroxyl groups.

Research [55] showed that quercetin was the major dietary flavonoid, followed by kaempferol, luteolin, and apigenin in the Netherlands. The greatest dietary source of flavonoids include onions which is $29 \%$ of total intake (approximately $23 \mathrm{mg}$ /day expressed as aglycones).

Wojdylo et al. [56] measured antioxidant activity and phenolic compounds in 32 selected herbs. It was found that quercetin, luteolin, apigenin were predominant flavonoids in those herbs in addition to phenolic acids.

Yao et al. [57] studied the flavonoids in food sources for humans and the health aspects of flavonoids. It was indicated that cumin and peppermint were good sources of flavanones (Naringenin, eriodictyol); parsley and thyme are sources of flavones (apigenin, chrysin, luteolin, diosmetin), and onions are sources of flavonols (isorhamnetin, kaempferol, quercetin, myricetin, rutin).

Dimitrios [58] introduced extensive sources of natural antioxidants from fruits, vegetable, seeds, wine, and tea. It was demonstrated that different spices and herbs are important sources of natural phenolic antioxidants: flavones in parsley; carnosic acid, carnosol, rosmarinic acid, rosmanol in rosemary; carnosol, carnosic acid, lateolin, rosmanul, rosmarinic acid in sage; rosmarinic acid, phenolic acids, flavonoids in oregano; thymol, carvacrol, flavonoids, lubeolin in thyme; rosmarinic, carnosol, carvacrol, flavonoids in summer savory and Gingerol and related compounds in Ginger.

Study [54] revealed that Greek mountain oregano, hard sweet marjoram, Mexican oregano and sweet bay had higher total phenolic content in various herbal extracts studied, with total phenolic content $11.8 \pm 0.60,11.65 \pm 0.29,17.51 \pm 0.22$, and $4.02 \pm 0.90 \mathrm{mg}$ GAE/g respectively (Results were expressed as milligrams of gallic acid equivalent (GAE) per gram of fresh weight).

Kähkönen et al. [59] measured the antioxidant activity of different plant extracts spectrometrically according to the Folin-Ciocalteu procedure and found the total phenolic content of bog-rosemary as calculated as GAE was even higher than that of all the vegetables and some fruits studied at the same time.

In a mini review, Embuscado summarized total phenolic content of spices and herbs from different researches [60]: allspice $421.5 \mu \mathrm{mol}$ gallic acid eq. per gram; basil $122.0 \mathrm{mg}$ per gram; black pepper $3.83 \mathrm{mg}$ per gram; coriander $18.5 \mu \mathrm{mol}$ gallic acid eq. per gram; cinnamon $157.18 \mathrm{mg}$ per gram; clove 113.19 mg per gram; cumin $49.5 \mu \mathrm{mol}$ Trolox eq. per gram; fennel $46.1 \mu \mathrm{mol}$ gallic 
acid eq. per gram; ginger $3.17 \mathrm{mg}$ per gram; parsley $15.5 \mathrm{mg}$ per gram; thyme $23.24 \mathrm{mg}$ per gram; turmeric $21.17 \mathrm{mg}$ per gram.

Shan et al. [26] found that cloves have the highest amount of flavonoids (366.5 as mg per $100 \mathrm{~g}$ ), followed by dill (241.2), caraway (171.9), coriander (167.2), oregano (51.3), rosemary (37.8), mint (23.2), basil (21.0), and sage (20.5).

A database [27] that contains data for 425 spices and culinary herbs from 59 countries was produced by a number of manufacturers. The antioxidant content was measured by modified ferric reducing antioxidant power (FRAP) assay. Antioxidants were extracted in water/methanol. Twenty-seven spices had the highest antioxidant content which varied from 100 to $465 \mathrm{mmol}$ per $100 \mathrm{~g}$. Shan et al. [26] showed the total antioxidant capacity of 26 spices from 12 botanical families as determined by TEAC. The phenolic content was measured using Folin-Ciocalteu assay. Colves, cinnamon and oregano were the three spices with the highest value. A high correlation $(R=0.9613)$ was found between the TEAC value and the total phenolic content.

It is not a surprising that spices and herbs are at the top of the list of 100 products with the highest antioxidant content [61,62]. Their antioxidant activities are ten times higher than that of fruit and vegetables. The antioxidant capacities of some spices showed a positive correlation with their corresponding total polyphenol concentrations.

\section{Methods for Antioxidant Extraction and Determination}

\subsection{Extraction Techniques for Antioxidant in Spices}

Extraction techniques aim to extract the active compounds from spices with certain selectivity and sensitivity. Several well-known methods have been used for extraction of active components from spices, such as liquid-phase extraction (extraction using solvents), solid-phase extraction, and supercritical fluid extraction (extraction using $\mathrm{CO}_{2}$ in its supercritical state) [63].

It was proven that different solvents or solvent mixture applied on the same spice sample can lead to different extraction efficiencies. A list of solvents used for extraction of spices has been provided by AllwynSundarRay et al. [25]. The solvents include methanol, methanol/water mixture (1:1), trichloroacetic acid, acetone, toluene, ethanol, ethyl acetate, and water. Methanol/water (1:1) and ethanol/water (1:1) mixtures are used most frequently. The total contents of flavonoids, polyphenols, and tannins in aqueous and methanolic extracts of cardamon, coriander, and bay leaf were different [50]. The results showed that the content of all these polyphenols in aqueous solutions of coriander was almost twice as much as that in the methanolic solutions. The opposite results were obtained for cardamon and bay leaf with polyphenol content in methanolic extracts significantly higher-2-3 times higher for cardamon and 3-10 times higher for bay leaf.

The extraction efficiency could be affected by the extraction temperature. Hot water extraction $\left(80-100{ }^{\circ} \mathrm{C}\right)$ has been used for measuring antioxidant activity of 13 spices [41]. The extraction lasted $3 \mathrm{~h}$. Antioxidant activity was determined by the 2,2-diphenyl-1-picrylhydrazyl (DPPH) method. However, the measurements may not be appropriate because a significant part of polyphenols could have been oxidized over $3 \mathrm{~h}$ at such high temperatures. Ereifej et al. [64] investigated the influence of different extractants (methanol, ethanol and acetone) at different temperatures $\left(20,40\right.$ and $\left.60^{\circ} \mathrm{C}\right)$. It was found that cloves had the highest level of total phenolics using methanol at three different temperature. When ethanol was used as extractant, cloves show the highest level of phenolics at $60{ }^{\circ} \mathrm{C}$. When acetone was used as an extractant at $60^{\circ} \mathrm{C}$, cloves still had the highest levels of total phenolics. The total phenolics of cloves were quite close using methanol and acetone as extractants.

To address the complexity of the extraction characteristics and optimize parameters for solvent extraction of phenolic compounds and antioxidants, response surface methodology by central composite design has been employed to statistically optimize the extraction conditions [65]. 


\subsection{Analytical Methods Applied to Antioxidant Capacities Determination in Spices}

A variety of methods have been used to determine antioxidant capacities in spices and herbs. The reported methods include 2,2-azino-bis(3-ehtylbenzothiazoline-6-sulfonic acid (ABTS) assay, DPPH radical scavenging activity, ORAC, ferric reducing antioxidant power (FRAP) and sensitive electrochemical and photochemiluminescent approaches, voltammetric and spectrophotometric methods [65-70]. Recently, a rapid approach based on near-infrared spectroscopy was developed for the determination of total polyphenols content and antioxidant activity in a Chinese herb [71]. Lu et al. [72] investigated the antibacterial effects of garlic concentrate by using Fourier Transform Infrared Spectroscopy. Similarly Venetsanou et al. [73] estimated antioxidant activity of different mixed herbal infusions using attenuated total reflectance Fourier transform infrared spectroscopy and chemometrics.

Antioxidant activities and antioxidant capacities of compounds from the same spices could be different depending on the analytical methods used. Antioxidant activity of ethanol and water/ethanol extracts of 13 spices have been evaluated by three different methods [51]. In many cases, water/ethanol extracts contained more antioxidants than ethanol extracts (measurements by $\mathrm{ABTS}^{+}$). When the same extracts were evaluated using photochemiluminescence or cyclic voltammetry, the results obtained for different spices shifted in both directions. Romero et al. [74] studied the antioxidant activities of a set of 17 active components present in different spices and condiment with different methods: (1) spectrophotometric method with DPPH radical scavenging assay and cupric reducing antioxidant capacity (CUPRAC) assay; (2) electrochemical method using either a mercury electrode or a glassy carbon electrode covered with poly-neutral rad and doped with $\mathrm{Pt}$ nanoparticles. The electrochemical method saves time for measurement and organic solvents for extraction. The sensitivity of electrochemical method is comparable with those shown by DPPH or CUPRAC.

Antioxidant activities from the same spices measured by different methods could be correlated. Dragland et al. [29] studied antioxidant activity of several dozen spices, culinary and medicinal (Chinese and Japanese) herbs. They reported that the antioxidant activity of these spices differs by as much as three orders of magnitude. Antioxidant activity in their study was determined by an automated FRAP assay. To compare these data to Carlsen et al. [28] using modified version of the FRAP assay, we correlated the two data sets and found their correlation was highly positive with correlation $>0.9$. A comparative study of antioxidant properties of 30 plant extracts using various methods-DPPH, ABTS, FRAP, superoxide dismutase (SOD), and ORAC assays demonstrated the different correlations among these methods [45]. The total polyphenol contents of cinnamon, cloves, bay leaf, vanilla, lavender and ginger were determined by Folin-Ciocalteu assay. The strongest correlation was found between the FRAP and ABTS assays (0.946), and the weakest was between ABTS and DPPH assays (0.906).

So far no single method will truly reflect the total antioxidant capacity of a particular sample. In order to fully reflect both lipophilic and hydrophilic capacity, elucidate a full profile of antioxidant capacity, and evaluate various reactive oxygen species, a number of methods are required. However, from the routine quality control point of view, it would be more practical to employ fewer, and standardized methods.

\section{Effect of Spices on Human Health and Other Applications}

Spices have been reported to have various beneficial effects on human health which include anti-sclerotic, antithrombotic, anti-carcinogenic, anti-inflammatory, antiarrhythmic, anti-rheumatic, gastroprotective, and lipid-lowering action. In addition, spices have radioprotective (protects against radiation), anti-allergic, and antimalarial effects. Spices inhibit the oxidation of low-density lipoprotein and protein glycation [75-79]. 
Many spices are highly potent antiseptics because they have an antibacterial, antimicrobial, and even antiviral effect. A synergistic effect on oral bacteria was observed when cloves were used along with antibiotics [80-84].

Spices and herbs have been used as functional food [85-89]. Table 4 shows various therapeutic effects of spices from different literatures.

Table 4. Reported therapeutic effects of spices in different diseases.

\begin{tabular}{ccc}
\hline Diseases & Spices & References \\
\hline $\begin{array}{c}\text { Cardiovascular diseases, including heart attack } \\
\text { neurodegenerative diseases }\end{array}$ & Garlic, turmeric, ginger & {$[90-92]$} \\
Antidiabetic action & Mint, onion & {$[93]$} \\
Gastrointestinal diseases & Cinnamon, bay leaf, wormwood, & {$[94,95]$} \\
Hypertension & fenugreek, mustard, pomegranate & {$[96,97]$} \\
Hepatic diseases & Black pepper, bay leaf & {$[98,99]$} \\
Endocrine diseases & Cardamon, cinnamon & {$[43,100]$} \\
Against DNA oxidation & Caraway, cardamon & {$[87]$} \\
Obesity & Ginger, turmeric & {$[101]$} \\
Bone diseases & Basil & {$[102]$} \\
Protection against oxidative damage to red blood cells & Saffron, turmeric & {$[103]$} \\
Immunomodulatory action & Cloves & {$[104]$} \\
Renal diseases & Fenugreek, garlic & {$[105,106]$} \\
Antiulcer action & Turmeric & {$[107,108]$} \\
Pigment cell growth inhibition & Garlic, fennelflower, ginger & {$[109]$} \\
Reduction of cortisol level in saliva & Ginger & {$[110]$} \\
Against alcohol abuse & Turmeric & {$[111]$} \\
Against gum disease & Lavender, rosemary & {$[112]$} \\
\hline
\end{tabular}

The therapeutic effects of certain spices are so significant that they have often been included in non-clinical, clinical, and therapeutic studies. A non-clinical trial of rosemary showed that rosemary could act as a cancer prevention agent. Some clinical and therapeutic trials for evaluation of spices against several diseases have been conducted. Studies show that curcumin possesses anti-inflammatory effects and therapeutic effect in gastrointestinal diseases. It is an inhibitor of low density lipoprotein oxidation and also showed effects against neurodegenerative diseases. Ginger and garlic have extensively therapeutic effects [90,91,114-120], especially for cardiovascular diseases. These will be reviewed in following section.

Cloves, Nigella, black pepper, garlic, and ginger have been used against cancer [121-123]. Aged aqueous-alcoholic extract of garlic was also reported to be potentially effective against certain cancers [124]. Table 5 summarizes anticancer actions of some spices. The following compounds contained in spices have anti-carcinogenic properties: curcumin, apigenin, luteolin, quercetin, thymoquinone, and isothiocyanate.

Table 5. Spices against cancer.

\begin{tabular}{ccc}
\hline Spices & Cancer Type & References \\
\hline Turmeric & Rectal cancer, oral cancer, leukemia, carcinoma of the head and neck & {$[125,126]$} \\
Saffron & Skin carcinoma, rectal cancer, hepatic carcinoma & {$[127-129]$} \\
Garlic & Prostate cancer, colon cancer & {$[130,131]$} \\
Onion & Gastric carcinoma & {$[132]$} \\
Turmeric & Leukemia & {$[133]$} \\
Mustard & Rectal carcinoma, bladder cancer & {$[134,135]$} \\
Bay leaf & Inhibits melanoma cell growth & {$[136]$} \\
Mustard (seeds) & Rectal carcinoma, bladder cancer & {$[137]$} \\
\hline
\end{tabular}

Some spices play a critical role in the management of heart disease (Table 6) because these spices have been shown to inhibit enzymes involved in lipid synthesis, decrease platelet aggregation, prevent lipid peroxidation, reduce LDL (low-density lipoprotein) levels and increase coronary blood flow. 
Table 6. Major bioactive compounds of spices with potential beneficial effects for the management of CVD (Cardiovascular disease).

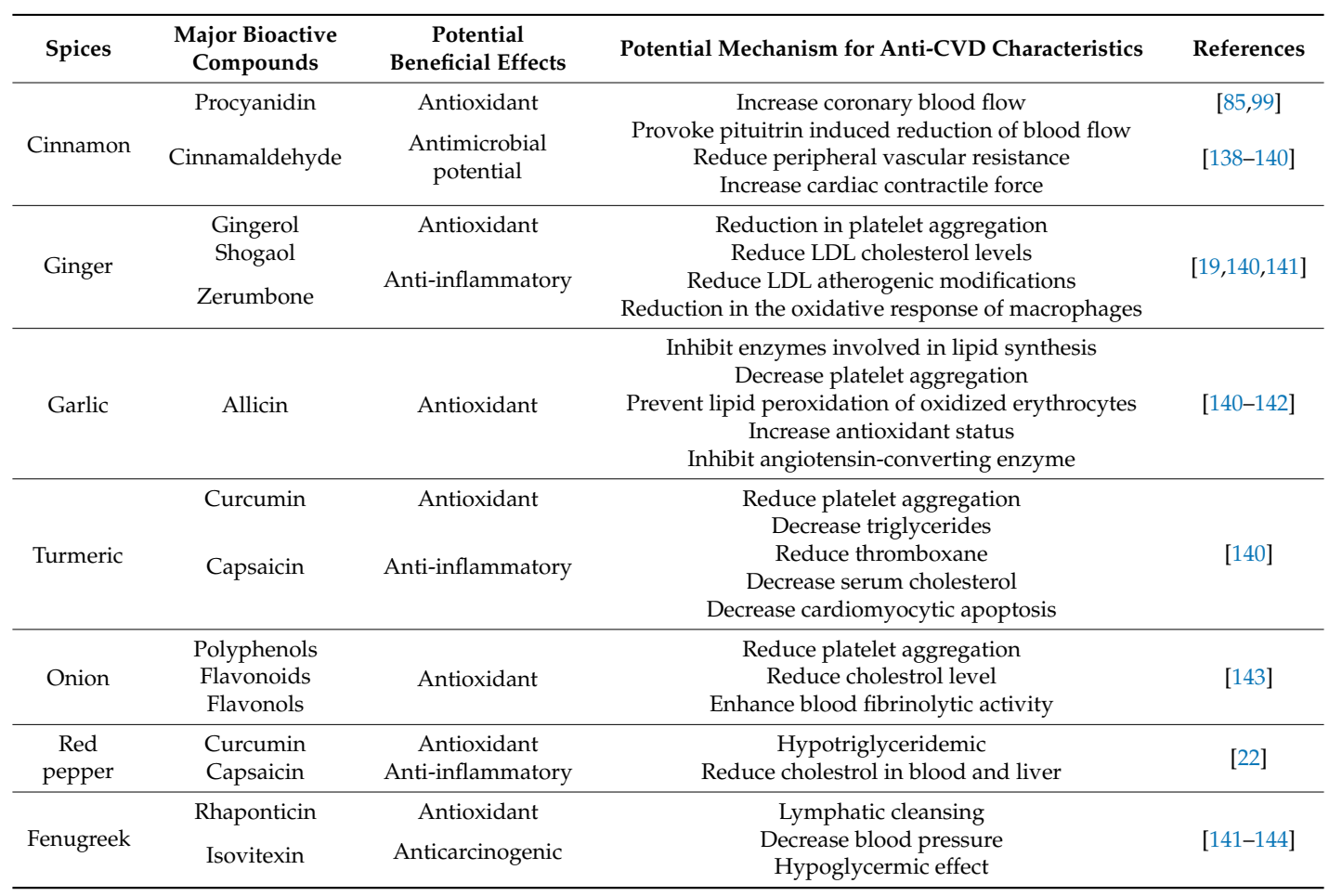

Spices have been used to preserve food to inhibit or delay lipid oxidation and rancidity in foods. Since ancient times it has been known that spices help preserve many foods. Now the application of spices have become even more broad: extension of cheese shelf-life by adding cinnamon; preservation of vitamin $\mathrm{E}$ in sunflower oil by adding different spices; inhibition of omega-3 fatty acid oxidation in vegetable oils by oregano and rosemary as well as sterol oxidation in extra virgin olive oil; extension of meat shelf-life by various spices [145-149].

Due to high antioxidant activity, spices suppress harmful effects of carcinogenic pollutants that may be present in foods and beverages, especially aflatoxins, heterocyclic amines, acrylamide, 1,2-Dimethylhydrazine and cadmium [150-155]. Spices can also neutralize the harmful effects of hazardous solvents and motor exhaust emissions from road transport in urban areas [156]. Therefore, it is important and reasonable to encourage people to consume spices regularly in order to protect them from harmful environmental impacts, especially in large, polluted cities.

\section{Conclusions}

Based on the reviewed literature, we know that spices not only enhance the flavor, aroma, and color of food and beverages, but they can also protect people from acute and chronic diseases, due to their high antioxidant activity. This review presents abundant data on the antioxidant activities of spices and culinary herbs, as well as information related to their content of flavonoids and total polyphenols. Many of the antioxidants contained in spices have significantly high biological activities and are actively used in preclinical, clinical, and therapeutic trials investigating new treatments of diseases. It is possible that new spice-based drugs may be developed. This review also presents a strong body of evidence that spice consumption can reduce or even eliminate the harmful effects on humans from contaminants in foods and from the environment; this is even more important for people living in polluted cities. All of this information will hopefully add to an already high level of interest toward spices and culinary herbs. Spices and herbs should certainly be incorporated as integral parts of healthy, nutritious eating, and as functional food ingredients. 
Acknowledgments: Herewith, we thank John Hunter (FutureCeuticals, Inc.) for review and providing valuable advice for editing this manuscript.

Conflicts of Interest: The authors declare no conflict of interest.

\section{References}

1. Baselga-Escudero, L.; Souza-Mello, V.; Pascual-Serrano, A.; Rachid, T.; Voci, A.; Demori, I.; Grasselli, E. Beneficial effects of the Mediterranean spices and aromas on non-alcoholic fatty liver disease. Trends Food Sci. Technol. 2017, 61, 141-159. [CrossRef]

2. Patra, K.; Jana, K.; Mandal, D.P.; Bhattacharjee, S. Evaluation of the antioxidant activity of extracts and active principles of commonly consumed Indian spices. J. Environ. Pathol. Toxicol. Oncol. 2016, 35, 299-315. [CrossRef] [PubMed]

3. Singhal, P.; Singla, N.; Sakhare, D.; Sharma, K.A. A comparative evaluation of in vitro antioxidant activity of some commonly used spices of northern India. Nat. Prod. J. 2017, 7, 131-136. [CrossRef]

4. Ene-Obong, H.; Onuoha, N.; Aburime, L.; Mbah, O. Chemical composition and antioxidant activities of some indigenous spices consumed in Nigeria. Food Chem. 2017. [CrossRef] [PubMed]

5. Bi, X.; Lim, J.; Henry, C.J. Spices in the management of diabetes mellitus. Food Chem. 2017, 217, $281-293$. [CrossRef] [PubMed]

6. Serafini, M.; Peluso, I. Functional foods for health: The interrelated antioxidant and anti-inflammatory role of fruits, vegetables, herbs, spices and cocoa in humans. Curr. Pharm. Des. 2016, 22, 6701-6715. [CrossRef] [PubMed]

7. Peter, K.V. Handbook of Herbs and Spices; Woodhead Publishing Limited and CRC Press LLS: Cambridge, UK, 2001; Volume 1.

8. Peter, K.V. Handbook of Herbs and Spices; Woodhead Publishing Limited: Cambridge, UK, 2004; Volume 2.

9. McCormick. The History of Spices. Available online: http://www.mccormickscienceinstitute.com/ resources/history-of-spices (accessed on 30 May 2017).

10. Surh, Y.J. Chemopreventive Phenolic Compounds in Common Spices; Taylor and Francis: New York, NY, USA, 2006.

11. Parthasarathy, V.A.; Chempakam, B.; Zachariah, T.J. Chemistry of Spices; CABI: Oxfordshire, UK, 2008.

12. Charles, D.J. Antioxidant Properties of Spices, Herbs and Other Sources; Springer: New York, NY, USA, 2013; p. 612.

13. Choi, I.S.; Cha, H.S. Physicochemical and antioxidant properties of black garlic. Molecules 2014, 19, 16811-16823. [CrossRef] [PubMed]

14. Samah, N.A.; Mahmood, M.R.; Muhamad, S. The role of nanotechnology application in antioxidant from herbs and spices for improving health and nutrition: A review. Selangor Sci. Technol. Rev. 2014, 1, 17-23.

15. Sobolev, A.P.; Carradori, S.; Capitani, D.; Vista, S.; Trella, A.; Marini, F.; Mannina, L. Saffron samples of different origin. An NMR study of microwave-assisted extracts. Foods 2014, 3, 403-419. [CrossRef] [PubMed]

16. Yesiloglu, Y.; Audin, H.; Kilic, I. In vitro antioxidant activity of various extracts of ginger seed. Asian J. Chem. 2013, 25, 3573-3578.

17. Asha Devi, S.; Umasanker, M.E.; Babu, S. A comparative study of antioxidant properties in common Indian spices. Int. Res. J. Pharm. 2012, 3, 465-468.

18. Panpatil, V.V.; Tattari, S.; Kota, N.; Polasa, K. In vitro evaluation on antioxidant and antimicrobial activity of spice extracts of ginger, turmeric and garlic. J. Pharmacogn. Phytochem. 2013, 2, 143-148.

19. Tchombe, N.L.; Louajri, A.; Benajiba, M.N. Therapeutical effects of Ginger. ISESCO J. Technol. 2012, 8, 64-69.

20. Islam, S.; Nasrin, S.; Khan, M.A.; Hossain, A.S.; Islam, F.; Khandokhar, P.; Mollah, M.N.H.; Rashid, M.; Sadik, G.; Rahman, M.A.A.; et al. Evaluation of antioxidant and anticancer properties of the seed extracts of Syzygium fruticosum Roxb. growing in Rajshahi, Bangladesh. BMC Complement. Altern. Med. 2013, 13, 142. [CrossRef] [PubMed]

21. Srinivasan, K. Antioxidant potential of spices and their active constituents (on line). Crit. Rev. Food Sci. Nutr. 2014, 54, 352-372. [CrossRef] [PubMed]

22. Srinivasan, K. Dietary spices as beneficial modulators of lipid profile in condition of metabolic disorders and disease. Food Funct. 2013, 4, 503-521. [CrossRef] [PubMed] 
23. Bhattacharjee, S.; Sengupta, A. Spices in cancer prevention-An overview. Internet J. Nutr. Wellness 2008, 7, 1-16.

24. Kaefer, C.M.; Milner, J.A. The role of herbs and spices in cancer prevention. J. Nutr. Biochem. 2008, 19, 347-354. [CrossRef] [PubMed]

25. AllwynSundarRaj, A.; Aaron, S.; Seinenbalg, S.S.; Tiroutchelvamaa, D.; Ranganathan, T.V. Review on recent trends in isolation of antioxidants from spices and its biological effects of essential oils. J. Eng. Res. Appl. 2014, 4, 75-84.

26. USDA Database for the Flavonoid Content of Selected Foods. Release 3.1 (May 2014). Available online: https:/ / www.ars.usda.gov/ARSUserFiles/80400525/Data/Flav/Flav_R03-1.pdf (accessed on 30 May 2017).

27. Shan, B.; Cai, Y.Z.; Sun, M.; Corke, H. Antioxidant capacity of 26 extracts of spices and characterization their phenolic components. J. Agric. Food Chem. 2005, 53, 7749-7759. [CrossRef] [PubMed]

28. Carlsen, M.H.; Halvorsen, B.L.; Holte, K.; Bøhn, S.K.; Dragland, S.; Sampson, L.; Willey, C.; Senoo, H.; Umezono, Y.; Sanada, C.; et al. The total antioxidant content of more than 3100 foods, beverages, spices, herbs and supplements used worldwide. Nutr. J. 2010, 9, 3-11. [CrossRef] [PubMed]

29. Dragland, S.; Senoo, H.; Wake, K.; Holte, K.; Blomhoff, R. Several Culinary and medicinal herbs are important sources of dietary antioxidants. J. Nutr. 2003, 133, 1286-1290. [PubMed]

30. Otunola, G.A.; Afolayan, A.J. Evaluation of the polyphenol contents and some antioxidant properties of aqueous extracts of garlic, ginger, cayenne pepper and their mixture. J. Appl. Bot. Food Qual. 2013, 86, 66-70.

31. Gulcin, I. The antioxidant and radical scavenging activities of black pepper (Piper nigrum) seeds. Int. J. Food Sci. Nutr. 2005, 56, 491-499. [CrossRef] [PubMed]

32. Singh, R.; Singh, N.; Saini, B.S.; Rao, H.S. In vitro antioxidant activity of pet ether extract of black pepper. Indian J. Pharmacol. 2008, 40, 147-151. [CrossRef] [PubMed]

33. Jimenez-Alvarez, D.; Giuffrida, F.; Golay, P.A.; Cotting, C.; Lardeau, A.; Keely, B.J. Antioxidant activity of oregano, parsley, and olive mill wastewaters in bulk oils and oil-in-water emulsions enriched in fish oil. J. Agric. Food Chem. 2008, 56, 7151-7159. [CrossRef] [PubMed]

34. Spiridon, I.; Colceru, S.; Anghel, N.; Teaca, C.A.; Bodirlau, R.; Armatu, A. Antioxidant and total phenolic contents of oregano (Origanum vulgare), lavender (Lavandula angus and lemon balm (Melissa officinalis) from Romania. Nat. Prod. Res. 2011, 25, 1657-1661. [CrossRef] [PubMed]

35. Shim, S.M.; Yi, H.L.; Kim, Y.S. Bioaccessibility of flavonoids and total phenolic content in onions and its relationship with antioxidant activity. Int. J. Food Sci. Nutr. 2011, 62, 835-838. [CrossRef] [PubMed]

36. Cazzola, R.; Camerotto, C.; Cestaro, B. Anti-oxidant, anti-glycant, and inhibitory activity against a-amylase and a glucosidase of selected spices and culinary herbs. Int. J. Food Sci. Nutr. 2011, 62, 175-184. [CrossRef] [PubMed]

37. Amira, S.; Dade, M.; Schinella, G.; Rios, J.L. Anti-inflammatory, anti-oxidant, and apoptotic activities of four plant species used in folk medicine in the Mediterranean basin. Pak. J. Pharm. Sci. 2012, 25, 65-72. [PubMed]

38. Mimica-Dukic, N.; Bugarin, D.; Grbovic, S.; Mitic-Culafic, D.; Vukovic-Gacic, B.; Orcic, D.; Jovin, E.; Couladis, M. Essential oil of Myrtus communis L. as a potential antioxidant and anti-mutagenic agents. Molecules 2010, 15, 2759-2770. [CrossRef] [PubMed]

39. Romani, A.; Coinu, R.; Carta, S.; Pinelli, P.; Galardi, C.; Vincieri, F.F.; Franconi, F. Evaluation of antioxidant effect of different extracts of Myrtus communis L. Free Radic. Res. 2004, 38, 97-103. [CrossRef] [PubMed]

40. El-Ghorab, A.H.; Nauman, M.; Anjum, F.M.; Hussain, S.; Nadeem, M.A. Comparative study on chemical composition and antioxidant activity of ginger (Zingiber officinale) and cumin (Cuminum cyminum). J. Agric. Food Chem. 2010, 58, 8231-8233. [CrossRef] [PubMed]

41. Thippeswamy, N.B.; Naidu, A. Antioxidant potency of cumin varieties-Cumin, black cumin and bitter cumin-On antioxidant systems. Eur. Food Res. Technol. 2005, 220, 472-476. [CrossRef]

42. Kim, I.S.; Yang, M.R.; Lee, O.H.; Kang, S.N. Antioxidant activities of hot water extracts from various spices. Int. J. Mol. Sci. 2011, 12, 4120-4131. [CrossRef] [PubMed]

43. Samojlik, I.; Laki, N.; Mimica-Duki, N.; Dakovi-Svajcer, K.; Bozin, B. Antioxidant and hepatoprotective potential of essential oils of coriander (Coriandrum sativum L.) and caraway (Carum carvi L.) (Apiaceae). J. Agric. Food Chem. 2010, 58, 8848-8853. [CrossRef] [PubMed]

44. Hlavackova, H.; Samuelsen, A.B.; Malterud, K.E. Antioxidant activity in extracts from coriander. Food Chem. 2004, 88, 293-297. 
45. Dudonné, S.; Vitrac, X.; Coutiere, P.; Woillez, M.; Merillon, J.M. Comparative study of antioxidant properties and total phenolic content of 30 plant extracts of industrial interest using DPPH, ABTS, FRAP, SOD, and ORAC assays. J. Agric. Food Chem. 2009, 57, 1768-1774. [CrossRef] [PubMed]

46. Yao, Y.; Sang, W.; Zhou, M.; Ren, G. Phenolic composition and antioxidant activities of 11 celery cultivars. J. Food Sci. 2010, 75, C9-C13. [CrossRef] [PubMed]

47. Sun, T.; Xu, Z.; Wu, C.T.; Janes, M.; Prinyawiwatkul, W.; No, H.K. Antioxidant activities of different colored sweet bell peppers (Capsicum annuum L.). J. Food Sci. 2007, 72, S98-S102. [CrossRef] [PubMed]

48. Dall'Acqua, S.; Cervellati, R.; Speroni, E.; Costa, S.; Guerra, M.C.; Stella, L.; Greco, E.; Innocenti, G. Phytochemical composition and antioxidant activity of Laurus nobilis L. leaf infusion. J. Med. Food 2009, 12, 869-876. [CrossRef] [PubMed]

49. Ozcan, B.; Esen, M.; Sangun, M.K.; Coleri, A.; Caliskan, M. Effective antibacterial and antioxidant properties of methanolic extract of Laurus nobilis seed oil. J. Environ. Biol. 2010, 31, 637-641. [PubMed]

50. Deepa, G.; Ayesha, S.; Nishta, K.; Thankamani, M. Comparative evaluation of various total antioxidant capacity assays applied to phytochemical compounds of Indian culinary spices. Int. Food Res. J. 2013, 20, 1711-1716.

51. Przyrodzka, M.; Zielinska, D.; Ciesarova, Z.; Kukurova, K.; Zielinski, H. Comparison of methods for evaluation of the antioxidant capacity and phenolic compounds in common spices. LWT Food Sci. Technol. 2014, 58, 321-326. [CrossRef]

52. Vallverdú-Queralt, A.L.; Rejueiro, J.; Martínez-Huélamo, M.; Alvarenga, J.F.R.; Leal, L.N.; Lamuela-Raventos, R.M. A comprehensive study on the phenolic profile of widely used culinary herbs and spices: Rosemary, thyme, oregano, cinnamon, cumin and bay. Food Chem. 2014, 154, 299-307. [CrossRef] [PubMed]

53. Nagy, T.O.; Solar, S.; Sontag, G.; Koenig, J. Identification of phenolic components in dried spices and influence of irradiation. Food Chem. 2011, 128, 530-534. [CrossRef] [PubMed]

54. Zheng, W.; Wang, S.Y. Antioxidant activity and phenolic compounds in selected herbs. J. Agric. Food Chem. 2001, 49, 5165-5170. [CrossRef] [PubMed]

55. Cook, N.C.; Samman, S. Flavonoids-Chemistry, metabolism, cardiopretective effects and dietary sources. J. Nutr. Biochem. 1996, 7, 66-76. [CrossRef]

56. Wojdylo, A.; Oszmiański, J.; Czemerys, R. Antioxidant activity and phenolic compounds in 32 selected herbs. Food Chem. 2007, 105, 940-949. [CrossRef]

57. Yao, L.H.; Jiang, Y.M.; Shi, J.; Tomás-Barberán, F.A.; Datta, N.; Singanusong, R.; Chen, S.S. Flavonoids in food and their health benefits, Flavanones in cumin, peppermint, Flavones in parsley, thyme and Flavonols in onions. Plant Foods Hum. Nutr. 2004, 59, 113-122. [CrossRef] [PubMed]

58. Dinitrios, B. Sources of natural phenolic antioxidants. Trends Food Sci. Technol. 2006, 17, 505-512. [CrossRef]

59. Kähkönen, M.P.; Hopia, A.I.; Vuorela, H.J.; Rauha, J.; Pihlaja, K.; Kujala, T.S.; Heinonen, M. Antioxidant activity of plant extracts containing phenolic compounds. J. Agric. Food Chem. 1999, 47, 3954-3962. [CrossRef] [PubMed]

60. Embuscado, M. Spices and herbs: Natural sources of antioxidants-A mini review. J. Funct. Foods 2015, 18, 811-819. [CrossRef]

61. Jorgustin, K. Top 100 High ORAC Value Antioxidant Foods. Available online: http:/ / modernsurvivalblog. com/health/high-orac-value-antioxidant-foods-top-100/ (accessed on 3 June 2014).

62. Haytowitz, D.B.; Bhagwat, S. USDA Database for the Oxygen Radical Absorbance Capacity (ORAC) of Selected Foods, Release 2. Available online: http:/ / www.drmarcofranzreb.com/wp-content/uploads / 2013/04/ORAC-de-alimentos-2.pdf (accessed on 30 May 2017).

63. Xu, D.; Li, Y.; Meng, X.; Zhou, T.; Zhou, Y.; Zheng, J.; Zhang, J.; Li, H. Nautral antioxidants in foods and medicinal plants: Extraction, assessment and resources. Int. J. Mol. Sci. 2017, 18, 96. [CrossRef] [PubMed]

64. Ereifej, K.I.; Feng, H.; Rababah, T.M.; Tachtoush, S.H.; Al-U'datt, M.; Gammoh, S.; Al-Rabadi, G.J. Effect of extractant and temperature on phenolic compounds and antioxidant activity of selected spices. Food Nutr. Sci. 2016, 7, 362-370. [CrossRef]

65. Chowdhury, A.; Selvaraj, K.; Bhattacharjee, C.; Chowdhury, R. Optimization of the solvent extraction of phenolics and antioxidants from waste Cauliflower leaves (Brassica oleracea L.) using response surface methodology (RSM). IJBLST 2013, 5, 4-12. 
66. Katalinic, V.; Milos, M.; Kulisic, T.; Juki, M. Screening of 70 medicinal plant extracts for antioxidant capacity and total phenols. Food Chem. 2006, 94, 550-557. [CrossRef]

67. Magalhaes, L.M.; Segundo, M.A.; Reis, S.; Lima, J.L.F.C. Methodological aspects about in vitro evaluation of antioxidant properties. Anal. Chim. Acta 2008, 613, 1-19. [CrossRef] [PubMed]

68. Prior, R.L.; Wu, X.; Schaich, K. Standardized methods for the determination of antioxidant capacity and phenolics in foods, and dietary supplements. J. Agric. Food Chem. 2005, 53, 4290-4302. [CrossRef] [PubMed]

69. Zielińska, D.; Wiczkowski, W.; Piskula, M.K. Evaluation of photochemiluminescent, spectrophotometric and cyclic voltammetry methods for the measurement of the antioxidant capacity: The case of roots separated from buckwheat sprouts. Pol. J. Food Nutr. Sci. 2008, 58, 65-72.

70. Pisoschi, A.M.; Pop, A.; Cimpeanu, C.; Predoi, G. Antioxidant capacity determination in plants and plant-derived products: A review. Oxid. Med. Cell. Longev. 2016, 2016, 9130976. [CrossRef] [PubMed]

71. Ma, L.; Zhang, Z.; Zhao, X.; Zhang, S.; Lu, H. The rapid determination of total polyphenols content and antioxidant activity in Dendrobium officinale using near-infrared spectroscopy. Anal. Method 2016, 8, 4584-4589. [CrossRef]

72. Lu, X.; Rasco, B.A.; Jabal, J.M.F.; Aston, D.E.; Lin, M.; Kondel, M.E. Investigating antibacterial effects of garlic (Allium sativum) concentrate and garlic-derived organosulfur compounds on Campylobacter jejuni by using fourier transform infrared spectroscopy, raman spectroscopy, and electron microscopy. Appl. Environ. Microbiol. 2011, 77, 5257-5269. [CrossRef] [PubMed]

73. Venetsanou, A.; Anastasaki, E.; Gardeli, C.; Tarantilis, P.A.; Pappas, C.S. Estimation of antioxidant activity of different mixed herbal infusions using attenuated total reflectance Fourier transform infrared spectroscopy and chemometrics. Emir. J. Food Agric. 2017, 29, 149-155. [CrossRef]

74. Romero, M.P.R.; Brito, R.E.; Palma, A.; Montoya, M.R.; Mellado, J.M.R.; Rodríguez-Amaro, R. An electrochemical method for the determination of antioxidant capacities applied to components of spices and condiments. J. Electrochem. Soc. 2017, 164, B97-B102. [CrossRef]

75. Hlavackova Assayed, M.E. Radioprotective effects of black seed (Nigella sativa) oil against hemopoietic damage and immunosuppression in gamma-irradiated rats. Immunopharmacol. Immunotoxicol. 2010, 32, 284-296. [CrossRef] [PubMed]

76. Castellan, M.L.; Perrella, A.; Conti, F.; Salini, V.; Tete, S.; Madhappan, B.; Vecchiet, J.; De Lutiis, M.A.; Caraffa, A.; Cerulli, G. Role of quercetin (a natural herbal compound) in allergy and inflammation. J. Biol. Regul. Homeost. Agents 2006, 20, 47-52.

77. El Babili, F.; Bouajila, J.; Souchard, J.P.; Bertrand, C.; Bellvert, F.; Fouraste, I.; Moulis, C.; Valentin, A. Oregano: Chemical analysis and evaluation of its antimalarial, antioxidant, and cyto-toxic activities. J. Food Sci. 2011, 76, C512-C518. [CrossRef] [PubMed]

78. Naidu, A.K.; Thippeswamy, N.B. Inhibition of human low density lipoprotein oxidation by active principles from spices. Mol. Cell. Biochem. 2002, 229, 19-23. [CrossRef] [PubMed]

79. Dearlove, R.P.; Greenspan, P.; Hartle, D.K.; Swanson, R.B.; Hargrove, J.L. Inhibition of protein glycation by extracts of culinary herbs and spices. J. Med. Food 2008, 11, 275-281. [CrossRef] [PubMed]

80. Islam, R.; Khan, M.H. Antibacterial activity of natural spices on multiple drug resistant Escherichia coli isolated from drinking water, Bangladesh. Ann. Clin. Microbiol. Antimicrob. 2011, 10, 10.

81. Devi, K.P.; Nisha, S.A.; Sakthivel, R.; Pandian, S.K. Eugenol (an essential oil of clove) acts as an antibacterial agent against Salmonella typhi by disrupting the cellular membrane. J. Ethnopharmacol. 2010, 130, 107-115. [CrossRef] [PubMed]

82. Hlavackova, D.; Toroglu, S. Studies on antimicrobial activities of solvent extracts of different spices. J. Environ. Biol. 2011, 32, 251-256.

83. Ailahverdiyev, A.; Duran, N.; Ozguven, M.; Koltas, S. Antiviral activity of the volatile oils of Melissa officinalis L. against Herpes simplex virus type-2. Phytomedicine 2004, 11, 657-661. [CrossRef] [PubMed]

84. Moon, S.E.; Kim, H.Y.; Cha, J.D. Synergistic effect between clove oil and its major compounds and antibiotics against oral bacteria. Arch. Oral Biol. 2011, 56, 907-916. [CrossRef] [PubMed]

85. Gruenwald, J.; Freder, J.; Armbruester, N. Cinnamon and health. Crit. Rev. Food Sci. Nutr. 2010, 50, 822-834. [CrossRef] [PubMed]

86. Butt, M.S.; Sultan, M.T.; Butt, M.S.; Igbal, J. Garlic: Nature's protection against physiological threats. Crit. Rev. Food Sci. Nutr. 2009, 49, 538-551. [CrossRef] [PubMed] 
87. Butt, M.S.; Sultan, M.T. Nigella sativa-reduces the risk of various maladies. Crit. Rev. Food Sci. Nutr. 2010, 50, 654-655. [CrossRef] [PubMed]

88. Stajner, D.; Canadanovic-Brunet, J.; Pavlovic, A. Allium species. Phytother. Res. 2008, 22, 113-117. [PubMed]

89. Vinda-Martos, M.; Ruiz-Navajos, Y.; Fernandes-Lopes, J.; Perez-Alvarez, J.A. Spices as functional foods. Crit. Rev. Food Sci. Nutr. 2011, 51, 13-28. [CrossRef] [PubMed]

90. Gorinstein, S.; Leontowicz, H.; Leontowicz, M.; Namiesnik, J.; Najman, K.; Drzewiecki, J.; Cvikrova, M.; Martincova, O.; Katrich, E.; Trakhtenberg, S. Comparison of the main bioactive compounds and antioxidant activities in garlic and white and red onions after treatment protocols. J. Agric. Food Chem. 2008, 56, 4418-4426. [CrossRef] [PubMed]

91. Gorinstein, S.; Leontowicz, H.; Leontowicz, M.; Jastrzebski, Z.; Najman, K.; Tashma, Z.; Katrich, E.; Heo, B.G.; Cho, J.Y.; Park, Y.J.; et al. The influence of raw and processed garlic and onions on plasma classical and non-classical atherosclerosis indices: Investigations in vitro and in vivo. Phytother. Res. 2010, 24, 706-714. [CrossRef] [PubMed]

92. Rastogi, S.; Mohan Pandey, M.; Kumar Singh Rawat, A. Spices: Therapeutic potential in cardiovascular health. Curr. Pharm. Des. 2017, 23, 989-998. [CrossRef] [PubMed]

93. Hwang, I.K.; Lee, C.H.; Yoo, K.Y.; Choi, J.H.; Park, O.K.; Lim, S.S.; Kang, I.J.; Kwon, D.Y.; Park, J.; Yi, J.S.; et al. Neuroprotective effects of onion extract and quercetin against ischemic neuronal damage in the gerbil hippocampus. J. Med. Food 2009, 12, 990-995. [CrossRef] [PubMed]

94. Mills, E.; Koren, G. From type 2 diabetes to antioxidant activity: A systematic review of the safety and efficacy of common and cassia cinnamon bark. Can. J. Physiol. Pharmacol. 2007, 85, 837-847.

95. Khan, A.; Zaman, G.; Anderson, R.A. Bay leaves improve glucose and lipid profile of people with type 2 diabetes. J. Clin. Biochem. Nutr. 2009, 44, 52-56. [CrossRef] [PubMed]

96. Mehmood, M.H.; Gilani, A. Pharmacological basis for the medicinal use of black pepper and piperine in gastrointestinal disorders. J. Med. Food 2010, 13, 1086-1096. [CrossRef] [PubMed]

97. Speroni, E.; Cervellati, R.; Dall'Acqua, S.; Guerra, M.C.; Greco, E.; Govoni, P.; Innocenti, G. Gastroprotective effect and antioxidant properties of different Laurus nobilis L. leaf extracts. J. Med. Food 2011, 14, 499-504. [CrossRef] [PubMed]

98. Edwards, R.L.; Lyon, T.; Litwin, S.E.; Rabovsky, A.; Symons, J.D.; Jalili, T. Quercetin reduces blood pressure in hypertensive subjects. J. Nutr. 2007, 137, 2405-2411. [PubMed]

99. Davis, P.A.; Yokoyama, W. Cinnamon intake lowers fasting blood glucose: Meta-analysis. J. Med. Food 2011, 14, 884-889. [CrossRef] [PubMed]

100. Mallikarjuna, K.; Sahitya Chetan, P.; Sathyavelu Reddy, K.; Rajendra, W. Ethanol toxicity: Rehabilitation of hepatic antioxidant defense system with dietary ginger. Fitoterapia 2008, 79, 174-178. [CrossRef] [PubMed]

101. Beric, T.; Nikolic, B.; Stanojevic, J.; Vukovic-Gacic, B.; Knezevic-Vukcevic, J. Protective effect of basil (Ocimum basilicum L.) against oxidative DNA damage and mutagenesis. Food Chem. Toxicol. 2008, 46, 724-732. [CrossRef] [PubMed]

102. Alappat, L.; Awad, A.B. Curcumin and obesity: Evidence and mechanisms. Nutr. Rev. 2010, 68, 729-738. [CrossRef] [PubMed]

103. Karmakar, S.; Choudhury, M.; Das, A.S.; Maiti, A.; Majumdar, S.; Mitra, C. Clove (Syzygium aromaticum Linn) extract rich in eugenol and eugenol derivatives shows bone-preserving efficacy. Nat. Prod. Res. 2012, 26, 500-509. [CrossRef] [PubMed]

104. Kaviarasan, S.; Vijagalakshmi, K.; Anuradha, C.V. Polyphenol-rich extract of fenugreek seeds protect erythrocytes from oxidative damage. Plant Foods Hum. Nutr. 2004, 59, 143-147. [CrossRef] [PubMed]

105. Majdalawieh, A.F.; Carr, R.I. In vitro investigation of the potential immunomodulatory and anti-cancer activities of black pepper (Piper nigrum) and cardamom (Elettaria cardamomum). J. Med. Food 2010, 13, 371-381. [CrossRef] [PubMed]

106. Salem, M.L. Immunomodulatory and therapeutic properties of Nigella Sativa L. seed. Int. Immunopharmacol. 2005, 5, 1749-1770. [CrossRef] [PubMed]

107. Elbarbry, F.; Gazarin, S.; Shoker, A. The protective effect of thymoquinone, an anti-oxidant and anti-inflammatory agent, against renal injury: A review. Saudi J. Kidney Dis. Transpl. 2009, 20, 741-752.

108. Mahmoud, M.F.; Diaai, A.A.; Ahmed, F. Evaluation of the efficacy of ginger, Arabic gum and Boswellia in acute and chronic renal failure. Ren. Fail. 2012, 34, 73-82. [CrossRef] [PubMed] 
109. Hlavackova Singh, P.K.; Kaur, I.P. Synbiotic (probiotic and ginger extract) loaded floating beads: A novel therapeutic option in an experimental paradigm of gastric ulcer. J. Pharm. Pharmacol. 2012, 64, 207-217. [CrossRef] [PubMed]

110. Alex, A.F.; Spitznas, M.; Tittel, A.P.; Kurts, C.; Eter, N. Inhibitory effect of epigallocatechin gallate (EGCG), resveratrol, and curcumin on proliferation of human retinal pigment epithelial cells in vitro. Curr. Eye Res. 2010, 35, 1021-1033. [CrossRef] [PubMed]

111. Atsumi, T.; Tonosaki, K. Smelling lavender and rosemary increases free radical scavenging activity and decreases cortisol level in saliva. Psychiatry Res. 2007, 150, 89-96. [CrossRef] [PubMed]

112. Shati, A.A.; Elsaid, F.G. Effects of water extracts of thyme (Thymus vulgaris) and ginger (Zingiber officinale Roscoe) on alcohol abuse. Food Chem. Toxicol. 2009, 47, 1945-1949. [CrossRef] [PubMed]

113. Geoghegan, F.; Wong, R.W.; Rabie, A.B. Inhibitory effect of quercetin on periodontal pathogens in vitro. Phytother. Res. 2010, 24, 817-820. [PubMed]

114. Nyo, S.N.T.; Williams, D.B.; Head, R.J. Rosemary and cancer prevention-preclinical perspectives. Crit. Rev. Food Sci. Nutr. 2011, 51, 946-954.

115. Basnet, P.; Skalko-Basnet, N. Curcumin: An anti-inflammatory molecule from a curry spice on the path to cancer treatment. Molecules 2011, 16, 4567-4598. [CrossRef] [PubMed]

116. Goel, A.; Kunnumakkara, A.B.; Aggarwal, B.B. Curcumin as curecumin-from kitchen to clinic. Biochem. Pharmacol. 2008, 75, 787-809. [CrossRef] [PubMed]

117. Rajasekaran, S.A. Therapeutical potential of curcumin in gastrointerestinal deaseases. World J. Gastrointest. Pathophysiol. 2011, 2, 1-14. [CrossRef] [PubMed]

118. Aggarwal, B.B.; Harikumar, K.B. Potential therapeutic effects of curcumin, the anti-inflammatory agent, against neurodegenerative, cardiovascular, pulmonary, metabolic, autoimmune and neoplastic diseases. Int. J. Biochem. Cell Biol. 2009, 41, 40-59. [CrossRef] [PubMed]

119. Al-Suhaimi, E.A.; Al-Riziza, N.A.; Al-Essa, R.A. Physiological and therapeutical roles of ginger and turmeric on endocrine functions. Am. J. Chin. Med. 2011, 39, 215-231. [CrossRef] [PubMed]

120. Srinivasan, K. Ginger rhizomes (Zingiber officinale): A spice with multiple health beneficial potentials. FarmaNutition 2017, 5, 18-28. [CrossRef]

121. Randhawa, M.A.; Alghamdi, M.S. Anticancer activity of Nigella sativa (black seed)—A review. Am. J. Chim. Med. 2011, 39, 1075-1091. [CrossRef] [PubMed]

122. Shukla, Y.; Kolra, N. Cancer chemoprevention with garlic and its constituents. Cancer Lett. 2007, 247, $167-181$. [CrossRef] [PubMed]

123. Kundu, J.K.; Na, H.K.; Surth, Y.J. Ginger-derived phenolic substance with cancer preventive and therapentic potential. Forum Nutr. 2009, 61, 182-192. [PubMed]

124. Aguilera, P.; Chanez-Cardenas, M.E.; Ortiz-Plata, A.; León-Aparicio, D.; Espinoza-Rojo, M.; Villeda-Hernández, J.; Sánchez-García, A.; Maldonado, P.D. Aged garlic extract delays the appearance of infarct, an effect likely conditioned by the cellular antioxidant systems. Phytomedicine 2010, 17, 241-247. [CrossRef] [PubMed]

125. Villegas, I.; Sanches-Fidalgo, S.; de la Lastra, A. New mechanisms and therapeutic potential of curcumin for colorectal cancer. Mol. Nutr. Food Res. 2008, 52, 1040-1061. [CrossRef] [PubMed]

126. Wilken, R.; Veena, M.S.; Wang, M.B.; Srivatson, E.S. Curcumin: A review of anticancer properties and therapeutic activity in head and neck squamores cell carcinoma. Mol. Cancer 2011, 10, 12. [CrossRef] [PubMed]

127. Amin, A.; Hamza, A.A.; Bajbouj, K.; Ashraf, S.S.; Daoud, S. Saffron: A potential candidate for a novel anticancer drug against hepatocellular carcinoma. Hepatology 2011, 54, 857-867. [CrossRef] [PubMed]

128. Aung, H.H.; Wang, C.Z.; Ni, M.; Fishbein, A.; Mehendale, S.R.; Xie, J.T.; Shoyama, C.Y.; Yuan, C.S. Crocin from Crocus sativus possesses significant anti-proliferation effects on human colorectal cancer cells. Exp. Oncol. 2007, 29, 175-180. [PubMed]

129. Das, I.; Das, S.; Saha, T. Saffron suppresses oxidative stress in DMBA-induced skin carcinoma-a histopathological study. Acta Histochem. 2010, 112, 317-327. [CrossRef] [PubMed]

130. Kim, S.H.; Bommareddy, A.; Singh, S.V. Garlic constituent diallyl trisulfide suppresses x-linked inhibitor of apoptosis protein in prostate cancer cells in culture and in vivo. Cancer Prev. Res. 2011, 4, 897-906. [CrossRef] [PubMed] 
131. Zhou, Y.; Zhuang, W.; Hu, W.; Liu, G.J.; Wu, T.X.; Wu, X.T. Consumption of large amounts of Allium Vegetables reduces risk for gastric cancer in a meta-analysis. Gastroenterology 2011, 141, 80-89. [CrossRef] [PubMed]

132. Dorant, E.; van den Brandt, P.A.; Goldbohm, R.A.; Sturmans, F. Consumption of onions and a reduced risk of stomach carcinoma. Gastroenterology 1996, 110, 12-20. [CrossRef] [PubMed]

133. Angelo, L.S.; Kurzrock, R. Turmeric and green tea: A recipe for the treatment of beta-chronic lymphocytic leukemia. Clin. Cancer Res. 2009, 15, 1123-1125. [CrossRef] [PubMed]

134. Kim, H.Y.; Yokozawa, T.; Cho, E.J.; Cheigh, H.S.; Choi, J.S.; Chung, H.Y. In vitro and in vivo antioxidant effects of mustard leaf. Phytother. Res. 2003, 17, 465-471. [PubMed]

135. Bhattacharya, A.; Li, Y.; Wade, K.L.; Paonessa, J.D.; Fahey, J.W.; Zhang, Y. Allyl isothiocyanate rich mustard seed powder inhibits bladder cancer growth and muscle invasion. Carciogenesis 2010, 31, 2105-2110. [CrossRef] [PubMed]

136. Panza, E.; Tersigni, M.; Iorizzi, M.; Zollo, F.; De Marino, S.; Festa, C.; Napolitano, M.; Castello, G.; Lalenti, A.; Lanaro, A. Lauroside B-a megastigmane glycoside from Laurus nobilis (bay laurel) leaves, induces apoptosis in human melanoma cell lines by inhibitory NF-kB activation. J. Nat. Prod. 2011, 74, 225-233. [CrossRef] [PubMed]

137. Yuan, H.; Zhu, M.; Guo, W.; Jin, L.; Chen, W.; Brunk, U.T.; Zhao, M. Mustard seeds attenuate azoxymethane-induced colon carcinogenesis. Redox. Rep. 2011, 16, 38-44. [CrossRef] [PubMed]

138. Stavinoha, R.C.; Vattem, D.A. Potential neuroprotective effects of cinnamon. Int. J. Appl. Res. Nat. Prod. 2015, $8,24-46$.

139. Wang, Y.S. Pharmacology and Applications of Chinese Materia Medica; Peoples Health Publishers: Beijing, China, 1983.

140. Vasanthi, H.R.; Rarameswari, R.P. Indian spices for healthy heart-An overview. Curr. Cardiol. Rev. 2010, 6, 274-279. [CrossRef] [PubMed]

141. Bordia, A.; Verma, S.K.; Srivastava, K.C. Effect of ginger (Zingiber officinale Roscoe) and fenugreek (Trigonella foenumgraecum L.) on blood lipids, blood sugar and platelet aggregation in patients with coronary artery disease. Prostaglandins Leukot. Essent. Fatty Acids 1997, 56, 379-384. [CrossRef]

142. Rahman, K. Historical perspective on garlic and cardiovascular disease. J. Nutr. 2001, 131, 977-979.

143. Kleijnen, J.; Knipschild, P.; Terriet, G. Garlic onions and cardiovascular risk factors. A review of the evidence from human experiments with emphasis on commercially available preparations. Br. J. Clin. Pharmacol. 1989, 28, 535-544. [CrossRef] [PubMed]

144. Wani, S.A.; Kumar, P. Fenugreek: A review on its nutraceuticals properties and utilization in various food products. J. Saudi Soc. Agric. Sci. 2016. [CrossRef]

145. Shan, B.; Cai, Y.Z.; Brooks, J.D.; Corke, H. Potential application of spices and herb extracts as natural preservatives in cheese. J. Med. Food 2011, 14, 284-290. [CrossRef] [PubMed]

146. Beddows, C.G.; Jagait, C.; Kelly, M.J. Preservation of alpha-tocopherol in sunflower oil by herbs and spices. Int. J. Food Sci. Nutr. 2000, 51, 327-339. [PubMed]

147. Bhale, S.D.; Xu, Z.; Prinyawiwatkul, W.; King, J.M.; Godber, J.S. Oregano and rosemary extracts inhibit oxidation of long-chain n-3 fatty acids in menhaden oil. J. Food Sci. 2007, 72, C504-C508. [CrossRef] [PubMed]

148. D’Evoli, L.; Huikko, L.; Lampi, A.M.; Lucarini, M.; Lombardi-Boccia, G.; Nicoli, S.; Piironen, V. Influence of rosemary (Rosmarinus officinalis, L.) on plant sterol oxidation in extra virgin olive oil. Mol. Nutr. Food Res. 2006, 50, 818-823. [CrossRef] [PubMed]

149. Colindres, P.; Brewer, M.S. Oxidative stability of cooked, frozen, reheated beef patties: Effect of antioxidants. J. Sci. Food Agric. 2011, 91, 963-968. [CrossRef] [PubMed]

150. Nayak, S.; Sashidnar, R.B. Metabolic intervention of aflatoxin B1 toxicity by curcumin. J. Ethnopharmacol. 2010, 127, 641-644. [CrossRef] [PubMed]

151. Renzulli, C.; Galvano, F.; Pierdomenico, L.; Speroni, E.; Guerra, M.C. Effects of rosmarinic acid against aflatoxin $\mathrm{Bl}$ and ochratoxin-A-induced cell damage in a human hepatoma cell line (Hep G2). J. Appl. Toxicol. 2004, 24, 289-296. [CrossRef] [PubMed]

152. Puangsombat, K.; Smith, J.S. Inhibition of heterocyclic amine formation in beef patties by ethanolic extracts of rosemary. J. Food Sci. 2010, 75, T40-T47. [CrossRef] [PubMed] 
153. Cao, J.; Liu, Y.; Jia, L.; Jiang, L.P.; Geng, C.Y.; Yao, X.F.; Kong, Y.; Jiang, B.N.; Zhong, L.F. Curcumin attenuates acrylamide-induced cytotoxicity and genotoxicity in HepG2 cells by ROS scavenging. J. Agric. Food Chem. 2008, 56, 12059-12063. [CrossRef] [PubMed]

154. Srihari, T.; Sengottuvelan, M.; Nalini, N. Dose-dependent effect of oregano (Origanum vulgare L.) on lipid peroxidation and antioxidant status in 1,2-dimethylhydrazine-induced ran carcinogenesis. J. Pharm. Pharmacol. 2008, 60, 787-794. [CrossRef] [PubMed]

155. Ige, S.F.; Salawu, E.O.; Olaleye, S.B.; Adeeyo, O.A.; Badmus, J.; Adeleke, A.A. Onion (Allium cepa) extract prevents cadmium induced renal dysfunction. Indian J. Nephrol. 2009, 19, 140-144. [PubMed]

156. Izawa, H.; Kohara, M.; Aizawa, K.; Suganuma, H.; Inakuma, T.; Watanabe, G.; Taya, K.; Sagai, M. Alleviative effects of quercetin and onion on male reproductive toxicity induced by diesel exhaust particles. Biosci. Biotechnol. Biochem. 2008, 72, 1235-1241. [CrossRef] [PubMed]

(C) 2017 by the authors. Licensee MDPI, Basel, Switzerland. This article is an open access article distributed under the terms and conditions of the Creative Commons Attribution (CC BY) license (http://creativecommons.org/licenses/by/4.0/). 